Tropical Journal of Pharmaceutical Research November 2014; 13 (11): 1809-1813

ISSN: $1596-5996$ (print); 1596-9827 (electronic)

(C) Pharmacotherapy Group, Faculty of Pharmacy, University of Benin, Benin City, 300001 Nigeria.

All rights reserved.

Available online at http://www.tjpr.org

Original Research Article

http://dx.doi.org/10.4314/tjpr.v13i11.6

\title{
Effect of Ketoprofen on Immune Cells in Mice
}

\author{
Dawood Ahmad Hamdani ${ }^{1 *}$, Aqeel Javeed ${ }^{1}$, Muhammad Ashraf ${ }^{1}$, Jawad Nazir ${ }^{2}$ \\ and Aamir Ghafoor ${ }^{3}$ \\ ${ }^{1}$ Department of Pharmacology \& Toxicology, ${ }^{2}$ Department of Microbiology, ${ }^{3}$ University Diagnostic Lab, University of Veterinary \\ and Animal Science, Lahore-Pakistan
}

*For correspondence: Email: davidbhai@hotmail.com; Tel: +92 42 99211103; 03214400446; Fax: +92 4299211106

Received: 26 August 2014

Revised accepted: 21 October 2014

\begin{abstract}
Purpose: To study the immunosuppressant and immunopotentiating effects of ketoprofen on antibodyproducing cells.

Methods: Mice were given ketoprofen at doses of $1 \mathrm{mg} / \mathrm{kg} /$ day and $5 \mathrm{mg} / \mathrm{kg} / \mathrm{day}$ for seven days. Similarly polyinosinic-polycytidylic acid (Poly IC) and phosphate buffer saline (PBS) were used as positive and negative control, respectively, for seven days. After seven days, the mice were sacrificed and their spleens removed. Simultaneously, blood was withdrawn from the hearts of the mice and serum was separated from the blood. The spleen cells were analyzed by enzyme-linked immunospot (ELISPOT) while the serum was investigated by enzyme-linked immunosorbant (ELISA) to evaluate the effects of ketoprofen on the ability of individual cell to produce antibodies and antibody- mediated immune responses.

Results: Ketoprofen significantly $(p<0.001)$ reduced the ability of individual cells to produce antibodies. There was a significant difference $(p<0.001)$ in \% of spot forming cells of PBS treated negative control group (0.045\%) as against positive control (0.058 \%), $1 \mathrm{mg}$ ketoprofen $/ \mathrm{kg} /$ day $(0.037 \%)$ and $5 \mathrm{mg}$ ketoprofen $/ \mathrm{kg} /$ day $(0.032 \%)$ treated groups. The results of ELISA showed a significant $(p<0.005)$ difference in the absorbance values between negative control, positive control, ELISA control and ketoprofen treated groups. Absorbance was significantly $(p<0.005)$ reduced in ketoprofen-treated groups.

Conclusion: The ability of an individual cell to produce antibodies and antibody-mediated immune responses is suppressed by ketoprofen, suggesting that it is immunosuppressive, and thus indicating its potential application in patients with auto-immune disorders.
\end{abstract}

Keywords: Ketoprofen, Immunomodulatory, Immunosupressive, Antibody, Spot-forming cells, Polyinosinic-polycytidylic acid

Tropical Journal of Pharmaceutical Research is indexed by Science Citation Index (SciSearch), Scopus, International Pharmaceutical Abstract, Chemical Abstracts, Embase, Index Copernicus, EBSCO, African Index Medicus, JournalSeek, Journal Citation Reports/Science Edition, Directory of Open Access Journals (DOAJ), African Journal Online, Bioline International, Open-J-Gate and Pharmacy Abstracts

\section{INTRODUCTION}

Ketoprofen belongs to propionic acid class of NSAIDs with analgesic, anti-inflammatory and antipyretic effects $[1,2]$. It is most often prescribed for muscle pain, tissue injury, and joint pain and for laminitis [3].
The immune system has two main components i.e. cellular immunity and humoral immunity [4]. The choice of immune assays for a given clinical trial depends on the known or suggested immunomodulation mechanisms associated with the therapeutic modality [5]. Immune responses in human and in other species at the single cell level can be measured by ELISPOT assay. The effects on a single cell level can be measured 
without any manipulation or expansion of the cell population. ELISPOT assay is used to quantify antigen-specific T-cell immunity and is also used as a biomarker for monitoring the effects of immunomodulatory drugs [6]. ELISPOT assay is applied in the studies where counting of antigen specific cells is important. In the ELISPOT assay each antibody producing cell forms a black spot when the substrate is added. If the ability of the cell to produce antibodies is less the result will be a decrease in the percentage of spot forming cells.

ELISA is a very specific and sensitive method as compared to those of radioimmunoassay and has the advantage of automation. It is a widely accepted and reliable assay for the detection of antibody- mediated immune responses [7]. ELISA was developed for the determination of IgG with the help of immunoadsorbant and enzyme labeled antigens. It has an advantage way of running a large number of samples together and also to observe the antigen antibody response [8]. ELISA is routinely used to detect the effects of various drugs on the immune system.

Ketoprofen is frequently used to treat different medical conditions. It may affect immune system at therapeutically effective doses. Therefore in this study, we analyzed the effects of ketoprofen on the ability of an individual cell to produce antibodies by performing the ELISPOT assay and ELISA was performed to analyze the effects of ketoprofen on antibody mediated immune responses.

\section{EXPERIMENTAL}

Mice (5-6 weeks old) were weighed and divided into four groups i.e. negative control in which only PBS (Phosphate buffer saline) was administered, positive control in which polyinosinic-polycytidylic acid (Poly IC) (Catalogue \#4242-50, Sigma, Aldrich) was administered, $1 \mathrm{mg} / \mathrm{kg}$ ketoprofen treated and $5 \mathrm{mg} / \mathrm{kg}$ ketoprofen treated groups. Each group contained five mice $(n=5)$. Ketoprofen was purchased from Sigma Aldrich (Cat no. k1751$5 G)$. Mice in their respective groups were given ketoprofen, PBS and Poly IC for 7 days. All animal tests were carried out after obtaining ethical approval from the University of Veterinary and Animal Sciences Directorate of Advanced studies (ref no das/ 2054 dated 19-5-12 and in accordance with the IACUC Institutional Guidelines for the Care and Use of Laboratory Animals [9].

\section{ELISPOT assay}

After 7 days of treatment, mice were sacrificed and their spleens were removed. Spleen cells were separated on magnetic cell separator (MACS) using CD45R (B220) micro beads and further analyzed by ELISPOT for their ability to produce antibodies. Development of specific black spots indicated the ability of an individual cell to produce antibodies and accordingly the effects of ketoprofen, PBS and Poly IC on the antibody producing cells [10].

Specific multiscreen IP ELISPOT plates were used for the assay. Each well of the plate was made wet with $15 \mu \mathrm{L}$ of $35 \%$ ethanol for one minute. The plates were then rinsed with $150 \mu \mathrm{L}$ of sterile PBS three times before the ethanol evaporated. The plates were coated with 5 $\mu \mathrm{g} / \mathrm{mL}$ of (GPI) protein in sterile PBS and then incubated overnight at $4{ }^{\circ} \mathrm{C}$.

The primary antibody solution was decanted. Unbound antibodies were washed off with 150 $\mu \mathrm{L}$ of sterile water per well. Washing was repeated two times. The membrane of plates was blocked with $200 \mu \mathrm{L}$ per well of cell medium (10\% RPMI) for at least $2 \mathrm{~h}$ at $37^{\circ} \mathrm{C}$.

The Blocking medium was decanted from the plates and B cells separated from the spleen were added at a final concentration of $1 \times 10^{6}$ cells $/ \mathrm{mL}$ to each well on the plates. The plates were incubated for $6 \mathrm{~h}$ at $37^{\circ} \mathrm{C}, 5 \% \mathrm{CO}_{2}$ and 95 $\%$ humidity.

The Plates were washed three times with PBS $/ 0.01 \%$ Tween $20(100 \mu \mathrm{L}$ of Tween 20 in 1 L PBS). $100 \mu \mathrm{L}$ of secondary antibody Goatantimouse-IgG (Jackson Immuno Research Laboratories) was added to each well of the plate. The plates were incubated for $2 \mathrm{~h}$ at $37^{\circ} \mathrm{C}$, $5 \% \mathrm{CO}_{2}$ and $95 \%$ humidity.

Secondary antibody was decanted and washed three times with PBS/0.01\% Tween 20. The plates were then washed three times with PBS. $100 \mu \mathrm{L}$ of BCIP/NBT (5-bromo-4-chloro-3'indolyphosphate p-toluidine salt/ Nitro blue tetrazolium Chloride, Thermo, USA) plus substrate was added to each well and incubated for 5-10 min. Afterwards plates were washed extensively under running water to stop any spot development. The percentage of spot forming cells was calculated and the effect of ketoprofen on the ability of an individual cell to produce antibodies was analyzed by percentage of spot forming cells [11].

Trop J Pharm Res, November 2014; 13(11):1810 


\section{ELISA}

After treating the mice for seven days with PBS, poly-IC, $1 \mathrm{mg} / \mathrm{kg} /$ day ketoprofen and $5 \mathrm{mg} / \mathrm{kg} /$ day ketoprofen, the mice were sacrificed and the blood was withdrawn from the heart of the mice. The blood was centrifuged at 14500 RPM for 20 min and the serum was separated. The assay was evaluated employing ELISA. The following procedure was carried out to perform ELISA.

\section{Coating of plates}

The assay was carried out using polystyrene flatbottom plates coated with $100 \mu$ l of recombinant mouse GPI-GST at $5 \mu \mathrm{g} / \mathrm{mL}$ in PBS. The plates were then incubated for $24 \mathrm{~h}$ at $4{ }^{\circ} \mathrm{C}$ in a refrigerator. The plates were rinsed with wash buffer comprised of tween-20 and PBS. After rinsing, $200 \mu \mathrm{L}$ of blocking buffer was added to each of the well and then the plates were incubated at $37{ }^{\circ} \mathrm{C}$ for $30 \mathrm{~min}$. After incubation, the plates were rinsed again with washing buffer.

\section{Test samples}

Each of the sample was diluted in PBS (1:1000). The diluted serum was further diluted using serial dilution in ELISA plate. $125 \mu \mathrm{L}$ of the PBS diluted sample was added in to the first row of the plate. Then $100 \mu \mathrm{L}$ of PBS added in 2nd, 3rd and 4th row. From the first row $25 \mu \mathrm{L}$ was added in the second row and from 2nd in 3rd and from 3rd in 4th. $25 \mu \mathrm{L}$ was discarded from the last row. Plates were incubated for $1 \mathrm{hr}$ at room temperature and thereafter washed three times with wash buffer at room temperature.

\section{Detection}

One tablet of alkaline phosphate (Sigma, Aldrich) substrate was added to $5 \mathrm{~mL}$ of alkaline phosphate buffer and then $100 \mu \mathrm{L}$ of the freshly made tablet solution was added to each well at room temperature. After 5-10 min clear yellow color was seen. After the appearance of the color, $100 \mu \mathrm{L}$ of Stop solution ( $1 \mathrm{M} \mathrm{NaOH}$ ) was added to stop the reaction. The plate was then placed in ELISA reader and absorbance was measured at $405 \mathrm{~nm}$. The value of absorbance was compared between negative control, positive control, $1 \mathrm{mg} / \mathrm{kg}$ and $5 \mathrm{mg} / \mathrm{kg}$ ketoprofen treated groups. The value of absorbance indicated the amount of antibody titer from each group.

\section{Statistical analysis}

Data collected was analyzed using the SPSS for Windows version 13. One-way ANOVA and LSD post hoc were applied to see statistical differences between groups. Differences were considered significant at $p<0.05$.

\section{RESULTS}

There was a significant difference $(p<0.001)$ in the $\%$ of spot forming cells of negative control with positive control, $1 \mathrm{mg} / \mathrm{kg}$ ketoprofen and 5 $\mathrm{mg} / \mathrm{kg}$ ketoprofen treated groups. Spot forming cells significantly decreased $(p<0.05)$ in 5 $\mathrm{mg} / \mathrm{kg}$ ketoprofen treated group as compared to the negative control, positive control and $1 \mathrm{mg} / \mathrm{kg}$ ketoprofen treated group. These results indicate that ketoprofen significantly reduced the individual cell's ability to produce antibodies (Fig 1). Similar trends were seen in the succeeding rows. There was a significant decrease in the \% of spot forming cells in ketoprofen treated groups in 2nd and 3rd row of ELISPOT plates (Fig 2, 3).

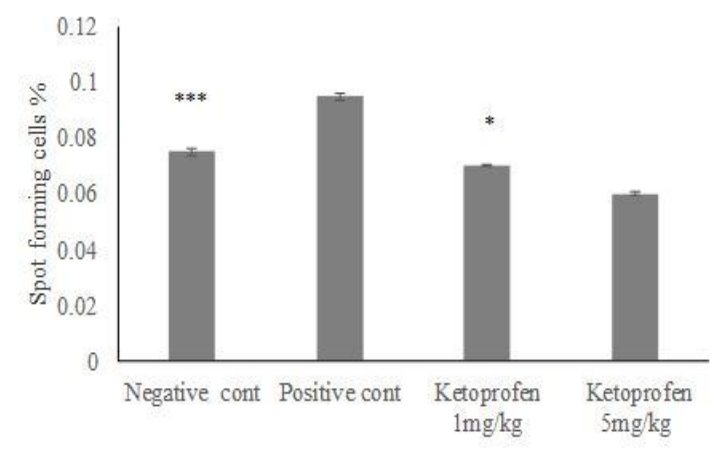

Figure 1: Antibody-producing cells forming black spots $\left(1^{\text {st }}\right.$ row); ${ }^{* * *} p<0.001$ compared with corresponding groups ${ }^{*} p<0.05$ compared to Negative control

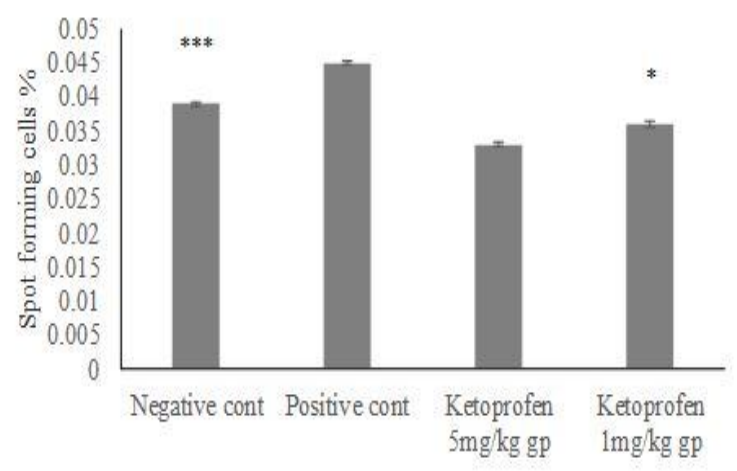

Figure 2: Antibody-producing cells forming black spots $\left(2^{\text {nd }}\right.$ row); ${ }^{* * *} p<0.001$ compared with corresponding groups; ${ }^{*} p<0.05$ compared to negative control

There was a significant $(p<0.005)$ difference in absorbance value between negative control, positive control, ELISA control and ketoprofen 
Table 1: Effect of ketoprofen on antibody producing cells measured by ELISA at $405 \mathrm{~nm}$ absorbance

\begin{tabular}{lccccc}
\hline Dilution of & \multicolumn{5}{c}{ Absorbance at 405 $\mathbf{~ n m}$} \\
sample & $\begin{array}{c}\text { Negative } \\
\text { control }\end{array}$ & $\begin{array}{c}\text { Positive } \\
\text { control }\end{array}$ & $\begin{array}{c}\text { Ketoprofen } \\
\mathbf{5 m g / k g}\end{array}$ & $\begin{array}{c}\text { Ketoprofen } \\
\mathbf{1 m g} / \mathbf{k g}\end{array}$ & $\begin{array}{c}\text { ELISA } \\
\text { Control }\end{array}$ \\
\hline $1: 1000$ & $0.853 \pm 0.13^{*}$ & $1.4505 \pm 0.03$ & $0.595 \pm 0.08$ & $0.798 \pm 0.08$ & $1.938 \pm 0.04$ \\
$1: 10000$ & $0.249 \pm 0.02^{*}$ & $0.6375 \pm 0.06$ & $0.154 \pm 0.02$ & $0.21 \pm 0.022$ & $1.191 \pm 0.01$ \\
$1: 100000$ & $0.193 \pm 0.003^{*}$ & $0.258 \pm 0.03$ & $0.101 \pm 0.002$ & $0.108 \pm 0.002$ & $0.431 \pm 0.01$ \\
$1: 1000000$ & $0.129 \pm 0.001^{*}$ & $0.17 \pm 0.008$ & $0.162 \pm 0.008$ & $0.141 \pm 0.008$ & $0.298 \pm 0.004$ \\
\hline
\end{tabular}

Data are shown as mean \pm S.E $(n=5) ;{ }^{*} p<0.005$ compared to positive control, assay control and $5 \mathrm{mg} / \mathrm{kg}$ ketoprofen-treated group

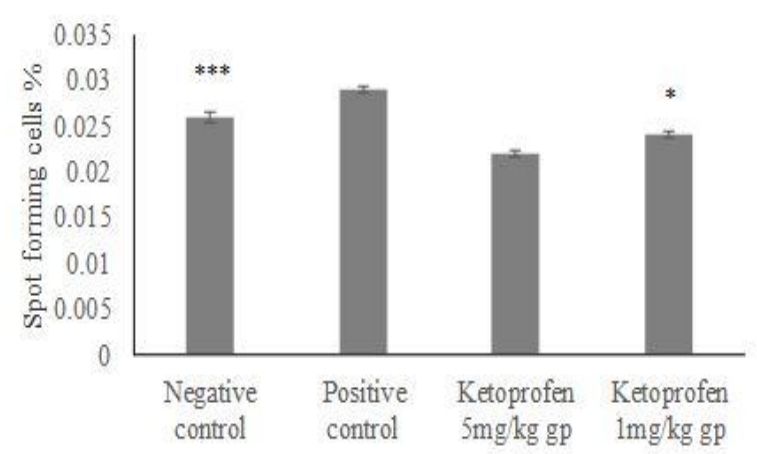

Figure 3: Antibody producing cells forming black spots $\left(\% \pm\right.$ S.E). ${ }^{* * *} p<0.001$ compared with corresponding groups; * $p<0.05$ compared to negative control

treated groups. Absorbance was significantly reduced in ketoprofen treated groups (Table 1). There was a significant decrease in absorbance at $5 \mathrm{mg} / \mathrm{kg}$ ketoprofen treated group. However there was no significant difference in absorbance between $1 \mathrm{mg} / \mathrm{kg}$ ketoprofen treated group and negative control. All these results indicated that the antibody titer was reduced in the ketoprofen treated mice.

\section{DISCUSSION}

Ketoprofen inhibits cycloxygenase COX and thereby inhibits prostaglandin synthesis [12]. Thus it produces anti-inflammatory, anti-pyretic and analgesic effects [13]. PGE2 regulates the immune response by inhibiting the production of cytokines and chemokines [14]. In this study, we analyzed the effects of ketoprofen on an individual cell's ability to produce antibodies and effects of ketoprofen on antibody mediated immune responses.

ELISPOT assay is most accurate and a widely used assay. After therapeutic immune modulation ELISPOT is a useful biomarker assay for predicting clinical benefit [15]. It is used for detecting Immune responses in human and in other species at the single cell level. The results of our study indicate that ketoprofen decreases single cell's ability to produce antibodies. There was a significant decrease in the percentage of spot formation in ketoprofen treated mice. The percentage of spot formation was also reduced when cells were diluted in 96 well ELISPOT plates. The decrease in the percentage of spot formation can be attributed to the immunosuppressive effect of ketoprofen on $\mathrm{T}$ cells or a decrease in B cell's ability to produce IgG, IgM antibodies. The decrease in antibody production results in a decrease in percentage of spot forming cells. Prior to this, effects of ketoprofen on immune modulation at the single cell level had not been studied. It can be assumed from our ELISPOT results that ketoprofen has immunosuppressive effects on individual cell's ability to produce antibodies.

ELISA is very specific and sensitive method comparable with those of radioimmunoassay and has the advantage of automation. It is widely accepted and most reliable assay for detection of antibody mediated immune responses [8]. ELISA was developed for the determination of $\lg G$ with the help of immunoadsorbant and enzymelabeled antigens. ELISA has an advantage of running a large number of samples simultaneously and also to evaluate the antigen, antibody response [9]. ELISA is routinely used to detect the effects of various drugs on the immune system. Our results indicate that ketoprofen has significantly reduced the amount of antibodies present in serum, which is reflected from the absorbance values.

\section{CONCLUSION}

The decrease in the ability of an individual cell to produce antibodies and decrease in antibody titer are considered to be due to immunosuppressive effects of ketoprofen on antibody producing cells. This indicates that ketoprofen treatment has immunosuppressive effects on immune cells, thus suggesting its potential usefulness in the treatment of autoimmune diseases. 


\section{ACKNOWLEDGEMENT}

Authors acknowledge Dr Hsin Jung Joyce Wu, Assistant Professor, Department of Immunobiology College of Medicine, University of Arizona, Tucson USA for her guidance and support. Authors also acknowledge financial support from Higher Education Commission, Islamabad, Pakistan, under its Indigenous PhD Program (Batch VI) and International Research Support Initiative Program (IRSIP).

\section{REFERENCES}

1. Celebi S, Hacimustafaoglu M, Aygun D, Arisoy E, Karali S, Akgoz Y, Citak AN, Seringec M. Antipyretic effect of ketoprofen. Indian J Pediatr. 2009; 76: 287-291.

2. Lu, WL, Zhang Q, Zheng L, Wang HLi, RY Zhang, Shen $L F, W B$ Tu $X D$. Antipyretic, analgesic and antiinflammatory activities of ketoprofen beta-cyclodextrin inclusion complexes in animals. Biol Pharm Bull. 2004; 27: 1515-1520.

3. Hiller A, Meretoja OA, Korpela R, Piiparinen S, Taivainen $T$. The analgesic efficacy of acetaminophen, ketoprofen, or their combination for pediatric surgical patients having soft tissue or orthopedic procedures. Anesth Analg. 2006; 102: 1365-1371

4. Kawai S, Uchida E, Kondo M, Ohno S, Obata J, Nawata $Y$, Sugimoto $K$, Oribe $M$, Nagaya I. Efficacy and Safety of Ketoprofen Patch in Patients With Rheumatoid Arthritis. A Randomized, Double-Blind, Placebo-Controlled Study. J Clin Pharmacol. 2010; 1: 103-109.

5. Whay HR, Webster AJ, Waterman-Pearson AE. Role of ketoprofen in the modulation of hyperalgesia associated with lameness in dairy cattle. Vet Rec. 2005; 157: 729-733.
6. Danika W, Erica Yu, Steven S, Vibha J. Validation of an ELISPOT Based $T$ cell Biomarker Assay for Monitoring Effects of Immune Modulating Agent. The Journal of Immunology. 2007; 178: 132-133.

7. Moore KA, Werner C, Zannelli RM, Levine B, Smith ML. Screening postmortem blood and tissues for nine classes [correction of cases] of drugs of abuse using automated microplate immunoassay. Forensic Sci Int. 1999; 106: 93-102.

8. Avrameas S. Historical background of the invention of EIA and ELISA. Clin Chem. 2006; 52: 1430-1431.

9. Guidelines and policies for the use of laboratory animals care and use policies available online at https://www.aalas.org/iacuc/laws-policies-guidelines\#.U-54KvmSwrZ.

10. Chambers IR, Cone TR, Oswald-Richter $K$ \& Drake wp. Enzyme-linked immunospot assay (ELISPOT): Quantification of Th-1 immune responses against microbial antigens. J VIS EXP. 2010; 45: 2221-2229.

11. Simona B, Matthew $P$, David J, Richard $P$. Ibuprofen and other widely used non-steroidal anti-inflammatory drugs inhibit antibody production in human cells. Cell immunol. 2009; 258(1): 18-28.

12. Sommerauer M, Ates M, Guhring $H$, Brune K, Amann R, Peskar BA. Ketoprofen-induced cyclooxygenase inhibition in renal medulla and platelets of rats treated with caffeine. Pharmacolog. 2001; 63: 234-239.

13. Dammann HG. 1999. Preferential COX-2 inhibition: its clinical relevance for gastrointestinal non-steroidal anti-inflammatory rheumatic drug toxicity. Z Gastroenterol. 37: 45-58.

14. Kuroda E. Yamashita U. [Regulation of immune responses by prostaglandin]. J. UOEH. 2002; 24: 289-299.

15. Slota M, Lim JB, Dang $Y$, Disis ML. ELISpot for measuring human immune responses to vaccines. Expert Rev Vaccines. 2011; 10(3): 299-306. 